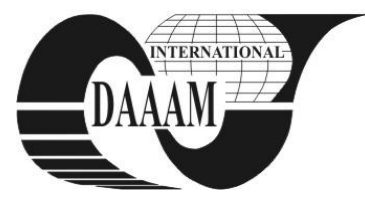

Annals of DAAAM for 2011 \& Proceedings of the 22nd International DAAAM Symposium, Volume 22, No. 1, ISSN 1726-9679 ISBN 978-3-901509-83-4, Editor B. Katalinic, Published by DAAAM International, Vienna, Austria, EU, 2011 Make Harmony between Technology and Nature, and Your Mind will Fly Free as a Bird Annals \& Proceedings of DAAAM International 2011

\title{
IMPROVING QUAY CRANES EXPLOITATION IN CONTAINER TERMINALS
}

\author{
BOCANETE, P[aul] \& DRAGOMIR, M[aria] C[ristina]
}

\begin{abstract}
This paper presents the dual cycling operation of quay cranes as a method to improve cranes exploitation and productvity in container terminals. There are presented some examples of quay cranes dual-cycle exploitation in different container terminals and other improvements in high technology handling system.
\end{abstract}

Key words: quay crane, exploitation, container terminal

\section{INTRODUCTION}

Cranes are one of the most useful and versatile piece of equipment used in a construction site or a container terminal. In the shipping industry, the most used types of cranes are the quay cranes, especially in container terminals.

The current trend in port operations research focuses on developments of automated guided vehicles, automated lifting vehicles, automated storage cranes and double trolley quay cranes to increase the trough put of modern container terminals. (Seyed et al., 2011)

A container terminal is a part of a port territory used for loading and unloading containers to and from a set of ships, and storing the containers in the terminal yard. Each ship is served by multiple quay cranes, which load and unload containers to and from ships. Containers are moved between the ships and the yard using a fleet of vehicles, each with unit capacity (Bish, 2003).

An operation schedule for quay cranes can significantly affect the turnaround time of a vessel. Recently dual cycling techniques have already been used for reducing the number of operation cycles of quay cranes in some advanced container terminals. Zhang and Kim studied minimization of the number of operation cycles of a quay cranes for discharging and loading containers in a ship-bay, which is equivalent to maximizing the number of dual cycle operations (Zhang \& Kim, 2009).

\section{IMPROVING QUAY CRANES EXPLOITATION}

In order to improve exploitation and to be performant, a container terminal must minimize discharging and loading operation times. When a terminal is planned, the water depth of the terminal and the outreach of the container cranes must be determined according to the size including the draught and width of the vessels. Therefore, the container terminals must prepare better calling conditions in terms of infrastructure and stevedoring system for very large container ships (Yang, 2004).

In most container ports, there are three main types of equipments involved in the loading and discharging process: quay cranes, yard trucks and yard cranes. For example, a loading operation of containers consists in picking up the desired container by a yard crane load it onto a yard truck and transporting it to a quay crane which will load the container on the containership.
Quay cranes can significantly influence the turnaround time of a vessel and several studies were made in solving and optimizing the quay cranes scheduling problems.

An operational method to improve the productivity of such crane is the dual cycle operation in discharging and loading operations, though most container terminals use the single cycle method in which the crane handles loading activities after all unloading tasks have been finished. In this case, the crane makes more empty movements. The dual cycling allows quay crane to discharge a container in the same cycle as a loading operation, thus doubling the number of tasks in one cycle, and decreasing the empty movements. Such a method improves quay crane exploitation efficiency and increases the berth productivity (Zhang \& Kim, 2009). Further, double cycling can reduce operating time by $10 \%$, improving vessel, crane and berth productivity (Goodchild \& Daganzo, 2007)

Quay cranes are, in general, immobile compared to yard cranes while yard cranes can serve a large region in the storage area. Managing, controlling and operating quay cranes is complex. For a better exploitation, details regarding optimal storage location for each container, schedule of of quay cranes operations and strategies to avoid congestion and unused timing should be well known.

Bish decomposed and analyzed the problem of improving exploitation into two levels: (1) dispatching vehicles to containers, assigning unloaded containers to storage locations, and determining the schedule of loading and unloading operations on the quay cranes, and (2) locating yard cranes in the storage area and determining the sequence of locations served by each yard crane. He treated the decisions in (2) as the decisions that should be considered in real-time control once the decisions in (1) are made. This is due to the fact that yard cranes are highly mobile, and thus, can be dispatched to yard locations in real-time control. Finally, such issues as traffic control, congestion, vehicle and crane failures are also ignored and left as issues to be considered during real-time control (Bish, 2003).

Zhang and Kim made a research of minimizing the total number of cycles of QC activities on one ship instead of the traditional makespan. This substitution was based on two assumptions: the number of cycles was considered as a proxy of the operation time for a quay crane to complete all the discharging and the loading operations in a ship-bay and the operation of quay cranes reprresents the bottleneck during the vessel operation and so the throughput rate of quay cranes determines the throughput rate of the integrated handling system consisting of quay cranes transporters, and yard cranes. A mixed integer linear programming model was suggested for this problem. To solve this model, the dual cycling quay crane scheduling problem was discomposed into intra-stage optimization phase (sequencing all stacks in one hatch), and inter-stage optimization phase (sequencing all hatches). An effective gap-based local search technique has been proposed for combining it with some reformulated heuristic approaches to obtain optimal hatch and stack sequences in the quay crane scheduling. They used some numerical experimental data from 
real cases to prove the effectiveness of the proposed approach. The experimental results showed that their proposed approach found the optimal solution in most of all cases, and greatly outperformed the real schedules constructed by human planners (Zhang \& Kim, 2009).

\subsection{Examples of quay cranes dual-cycle exploitation in different container terminals}

Some container terminals have already begun to use the dual-cycle exploitation strategy in practice.

For example, in November 2009, state-owned South African terminal operator Transnet Port Terminals (TPT) has launched dual cycle operations at Cape Town container terminal, increasing crane productivity by $41 \%$. The system sees quayside gantries performing both unloading and loading operations almost simultaneously, a system that it piloted with Maersk in recent months. During the latest of these trials, when it served the Maersk Dryden at the beginning of November, gross crane moves per hour shot up to 34 from its average of 24 , and the terminal achieved a ship working hour of 82. Instead of finishing a discharge across the vessel before doing a load operation, this is done simultaneously.

In Euromax Terminal from Rotterdam port, container vessels are handled using the largest quay cranes in the world, with semiautomatic operating system, second cat and other innovations.

Though, there are a range of challenges to introducing the system to every vessel and from the point of view of resourcing the terminal.

\section{OTHER QUAY CRANES IMPROVEMENTS}

Major ports are developing a high technology handling system to improve quay crane exploitation and loading and discharging productivity.

Shipping companies avoid calling at container terminals with low productivity in order to reduce their port laytime as the vessels become larger (Yang, 2004).

For a conventional post-Panamax crane, exploitation periods would be much longer if hoist and trolley speeds and accelerations were not significantly increased. For some crane operators, the automatic trolley drive helps, but up to now, the primary emphasis to decrease period has been increased speeds and accelerations. The elevating girder crane is identical to the conventional quay crane with one notable exception. The upper works can be raised or lowered before vessel service operations begin. The upper works can be parked at five levels so the lift height is $20,25,30,35$, or 40 meters ( 65 to 130 feet) above the quay. This reduces the distance from the trolley to the spreader and improves load control. Additional maintenance is required for the upper works lifting and locking components.

A spreader capable of handling tandem forties can pick two forty-foot containers in each lift. Such spreader includes a side shift mechanism that balances the difference in container weights in order to increase production for some operations.

Today, a dual hoist crane will be more productive than a dual trolley crane. The initial and operating cost of the two crane styles are the same. There is no apparent advantage to the dual trolley crane.

Paceco has developed a quay supported machine, the Paceco BufferStation. The buffer is a rubber tired gantry that receives the container from the ship trolley and transfers it to the quay. This machine converts a conventional crane to a dual hoist crane. The buffer can operate on most existing quays without overloading the quay. Since the buffer is on rubber tires, it can be inserted and removed as needed and can be moved out of the way for maintenance.

Ship-in-a-Slip concept places cranes on both sides of the ship, doubling the total production. The slip width can handle ships up to 22 -wide. The quay cranes operate very close to each other and lasers and other fail-safe devices prevent collision. Simulation indicates that, with all cranes operating, the total production will be 300 lifts per hour. In addition to increased production, the ship in a slip provides more berths per length of bulkhead line.

The FloatTerm concept extends the shipin-a-slip concept. One side of the ship is serviced from the landside quay and the opposite side is serviced by cranes operating on a vessel. The vessel could have removable bridges to shore and could include barge-berthing slots or could work entirely within a bay, providing midstream container transfers. The vessel could be stabilized on legs that would be extended to the bay bottom or by counterweights located in the lower chambers of the vessel. The movement of the counterweights would be automatic and depend on the trolley position and load on each crane.

Some crane concepts employ only linear paths. The hoisting and traveling are independent. For the linear concepts discussed, the hoist lifts full height to the trolley girder elevation for every cycle. This adds time to the hoist time increment. Since the trolley does not travel, load control is much better. The time added due to a longer lift will be more than made up by the load control (Jordan, 2002).

\section{CONCLUSION}

In this paper I analyzed the advantages and the exploitation improvements of dual-cycle quay cranes in a container terminal, based on field observations and on other authors' findings.

Double cycling is a technique by which empty crane moves are converted into productive moves, as containers are loaded and unloaded simultaneously. Based on such results, today there are made several improvements for a better exploitation of quay cranes.

Considerable further analysis and algorithms must be conducted in order to determine reductions in the number of operations and operating time and to minimize the number of operations necessary to turn around a row of a ship, before quay crane exploitation reaches the highest efficiency.

\section{REFERENCES}

Bish, E. K. (2003). A multiple-crane-constrained scheduling problem in a container terminal. Production, Manufacturing and Logistics. European Journal of Operational Research, Vol. 144, p. 83, ISSN 0377-2217

Goodchild, A.V. \& Daganzo, C.F. (2007). Crane double cycling in container ports: Planning methods and evaluation, Transportation Research, Part B, Vol. 41, p. 875-891, ISSN 0191-2615

Seyed M. H.; Tang S. H.; Napsiah I. \& Mohd K. (2011). Optimization of Integrated Scheduling of Quay Cranes and Automated Guided Vehicles using Simulated Annealing Algorithm, Proceedings of the 2011 International Conference on Industrial Engineering and Operations Management, Kuala Lumpur, Malaysia, January 22 - 24, 2011

Yang, C. H. (2004). The impact of bigger vessels on shipping \& ports, Korea Maritime Institute, Available from: http://www.kmi.re.kr/english/data/publication/k2004_02.pd f, Accessed: 2011-03-25

Zhang, H. \& Kim, K. H. (2009). Maximizing the number of dual-cycle operations of quay cranes in container terminals, Computers \& Industrial Engineering, Vol. 56, pp. 979-992, ISSN 0360-8352

***(2010)http://www.cargosystems.net/freightpubs/cs/article.ht m?artid $=20017824401 \& s r c=$ rss - Transet goes dual cycle in Cape Town, Accessed on: 2011-03-25 